\title{
Development Of Accelerating Strategy On Improvement Of Study Program Accreditation In Accordance With 9 Criterias of BAN-PT In The State University Of Medan
}

\author{
Motlan \\ Faculty of Mathematics and Natural Science, \\ Universitas Negeri Medan, Medan, Indonesia \\ Deo Demonta Panggabean \\ Faculty of Mathematics and Natural Science, \\ Universitas Negeri Medan, Medan, Indonesia \\ Nurkadri \\ Faculty of Sport Science, \\ Universitas Negeri Medan, Medan, Indonesia \\ Mukti Hamjah Harahap \\ Faculty of Mathematics and Natural Science, \\ Universitas Negeri Medan, Medan, Indonesia

\section{Irfandi} \\ Faculty of Mathematics and Natural Science, \\ Universitas Negeri Medan, Medan, Indonesia \\ Albert Pauli Sirait \\ Faculty of Education, \\ Universitas Negeri Medan, Medan, Indonesia
}

\begin{abstract}
This study aims to develop a strategy to speed improvements accreditation at the State University of Medan. This research is a development (Research and Development / R \& D) with BMVIT policy development cycle. Data was collected using response sheets, questionnaires and questionnaires. The results obtained through this research are: 1) the target accreditation courses that will expire next year is ranked accreditation excellent, 2) the factors inhibiting the acceleration of accreditation in Study Program State University of Medan, among others: (a) a system that can be used to ease the study program to access the data; (B) The level of understanding of each course with the new accreditation system is still low; (C) The lack of assistance in preparing the study program accreditation instruments, while the supporting factors accelerating the increase in Study Program accreditation State University of Medan, among others: (a) Participation of the entire community of course is very good; (B) the infrastructure owned by their respective study program has been very adequate, 3) Strategy accelerated increase in Study Program accreditation State University of Medan, among others: (a). Perception related to the new accreditation system in stages; (B) Assistance study program in a sustainable and measurable; (C) Preparation of system data relating to the needs of accreditation instruments that can be accessed by programs with ease. while the supporting factors accelerating the increase in Study Program accreditation State University of Medan, among others: (a) Participation of the entire
\end{abstract}


community of course is very good; (B) the infrastructure owned by their respective study program has been very adequate, 3) Strategy accelerated increase in Study Program accreditation State University of Medan, among others: (a). Perception related to the new accreditation system in stages; (B) Assistance study program in a sustainable and measurable; (C) Preparation of system data relating to the needs of accreditation instruments that can be accessed by programs with ease. while the supporting factors accelerating the increase in Study Program accreditation State University of Medan, among others: (a) Participation of the entire community of course is very good; (B) the infrastructure owned by their respective study program has been very adequate, 3) Strategy accelerated increase in Study Program accreditation State University of Medan, among others: (a). Perception related to the new accreditation system in stages; (B) Assistance study program in a sustainable and measurable; (C) Preparation of system data relating to the needs of accreditation instruments that can be accessed by programs with ease. 3) Strategies accelerated increase in Study Program accreditation State University of Medan, among others: (a). Perception related to the new accreditation system in stages; (B) Assistance study program in a sustainable and measurable; (C) Preparation of system data relating to the needs of accreditation instruments that can be accessed by programs with ease. 3) The accelerated Strategies to increase accreditation of all study Programs in State University of Medan, among others: (a). Perception related to the new accreditation system in stages; (B) Assistance study program in a sustainable and measurable; (C) Preparation of system data relating to the needs of accreditation instruments that can be accessed by programs with ease.

Keywords: Research and Development, Strategy, Accreditation

\section{INTRODUCTION}

Under the legislation, accreditation is conducted to determine the feasibility of program and educational unit at formal and non-formal education channels on all levels and types of education, as a form of public accountability. Accreditation is done by the Government or an independent institution authorized by the Government to conduct accreditation objectively, fairly, transparently and comprehensively using instruments and criteria refer to the National Education Standards. For program and / educational unit at the college level, it was determined that the accreditation is done by the National Accreditation Board of Higher Education (BAN-PT) (Law No.20 / 2003, Article 60 and PP No.19 / 2005 Article 86.87 and 88).

The requirement for Graduate Studies Program to obtain accreditation status is also based on the imperative of Law No.14 / 2005, Articles 11 and 47, and PP No.74 / 2008 Article 13 which stipulates that the educator certification is obtained through professional education organized by universities that have programs provision of educational personnel accredited and designated by the Government. Furthermore, it also set out in the Ministerial Regulation $58 / 2008$, Article 4 that the undergraduate program (S1) education can be implemented at a college that meets the requirements, one of which, an accredited minimum B, except for PGSD, and PGTK / PG-ECD which is currently still the operating license assignment from the Ministry of Education.

In a system of increasingly autonomous organization of education, accountability, quality assurance and strategies for achievement of the objectives of education is in the hands of the college. Therefore, to protect the interests of the community as well as a consequence of public accuntability, the accreditation is an aspect to be considered by the college. This accreditation demands seemed to be a general awareness, and it is possible to grow further into the public accountability movement (public accountability movement). Therefore, it is reasonable, even to the demands of quality, if various agencies, both government and private, in recruiting new 
employees have started to require the accreditation status of the study program for college graduate applicants.

With substantial legal requirements and to ensure the quality of educational services provided, the courses-courses in universities as an educational unit must strive to achieve the best accreditation status. The success of this best gain accreditation status can increase public confidence in the institution and ultimately ensure the sustainability of the courses concerned. For that reason it's important to develop strategies to accelerate the acquisition of the accreditation status.

State University of Medan is the first university in North Sumatra who earned Accreditation with accreditation A decision by BAN-PT No.2988 / SK / BAN-PT / Akred / PT / XII / 2016. Accreditation University of Medan was certainly influenced by the ratings of accreditation in State University of Medan. In order to maintain accreditation A, State University of Medan must implement policies that can accelerate the improvement of accreditation in each subject. Currently State University of Medan has 72 courses that consist of: 2 courses DIII, 49 courses S1, S2 16 courses and 5 courses S3. Ranked by accreditation there are 26 accredited programs A, B 28 accredited programs, and 18 new courses that have not been accredited.

In accordance with statute changes State University of Medan, in 2018. The State University of Medan has formed a new institution that is the transformation of the Center for Quality Assurance (PPM), namely the Institute of Education Development and Quality Assurance (LPPMP). State University of Medan LPPMP has a role in monitoring and improving the quality of education in Study Program State University of Medan included in mentoring accreditation. Assistance for accreditation should be made considering some significant changes to the Instrument Program Accreditation (IAPS) 4.0 oriented outputs and outcomes using the 9 criteria of the 1.Visi, Mission, Objectives and Strategy; 2.Tata Tutors, Governance and Cooperation;3.Students; 4. Human Resources; 5. Foundation, Infrastructures; 6. Education; 7. Research; 8. services; and 9. Outcomes. In order to improve the accreditation quickly process that refers to the IAPS 4.0, then LPPMP State University of Medan need to develop a strategy of acquisition accelerated study program accreditation status in the environment State University of Medan. The purpose of this study is; (1) Check progress and ranking targets of accreditation within the next 5 years State University of Medan (factual and future conditions, (2) Determine the limiting factors and supporting the acceleration of accreditation in Study Program State University of Medan, (3) Knowing the strategy of accelerating the increase in Study Program accreditation State University of Medan.

\section{RESEARCH METHODS}

This research was conducted at the State University of Medan in the first semester of academic year 2019/2020. This study will be carried out during the six months from June to November 2019.

Judging from its approach, this research included in mixed methods research, which is a research approach that combines quantitative and qualitative research in a single study. The use of this approach is based on the consideration for the data collected in this study includes two types of data, namely quantitative and qualitative data. The method used in the research development of this policy refers to the policy development cycle BMVIT. Research flow diagram as can be seen in Figure 1. 


\section{Figure 1, Flowchart (fishbone) Research}

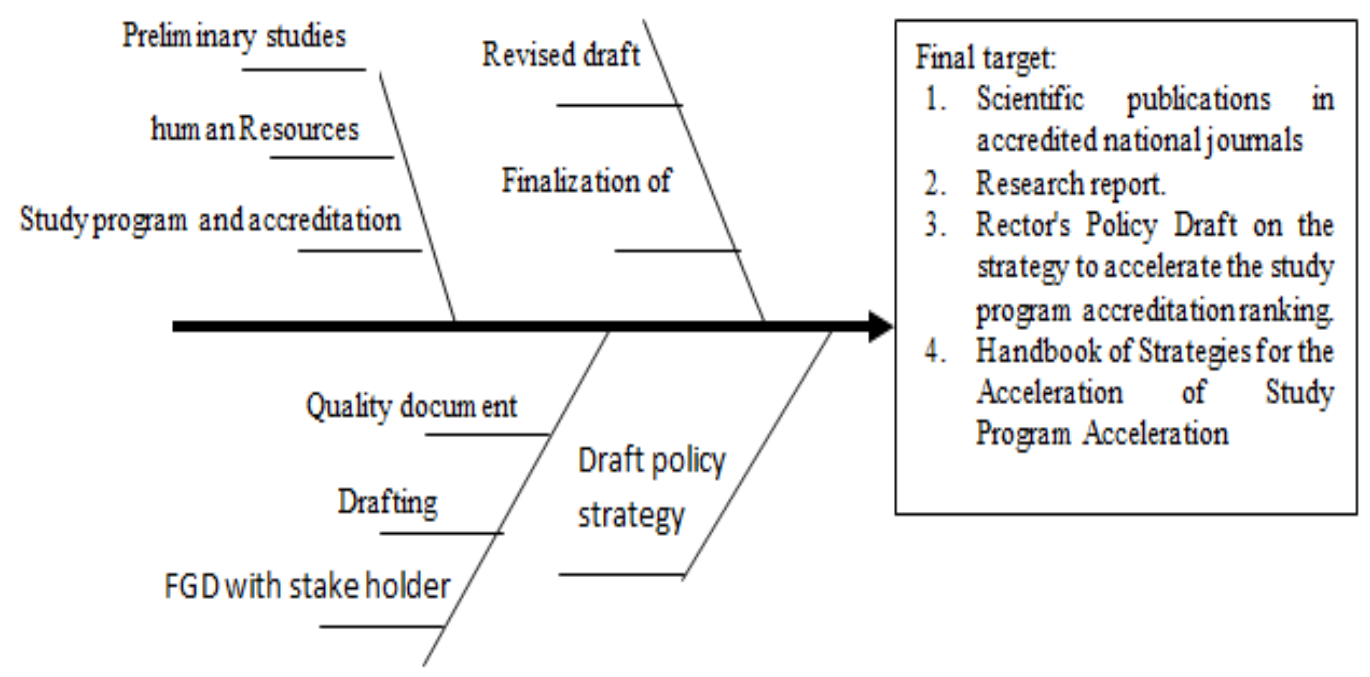

Data was collected using response sheets, questionnaires and questionnaires. Data obtained from this study is the quantitative and qualitative data.

Any data that has been collected will be analyzed by analysis of secondary data, often called existing statistics. Secondary data sources can be derived from the database of the university, faculty, courses, document statistical data or reports on the results of research and dedication. In the secondary data analysis study, researchers collected information resources via the source of the data found. Researchers rearrange or combine information into a new way to answer research questions.

\section{RESULTS}

This study begins with a perception amongst focus group discussion of researcher team and the parties involved in supporting the implementation of the study, so that all parties have the same understanding of the relevant stages of implementation and the role of each so that research can be run according to the plan that has been set. The research team has conducted preliminary data searches the number of courses and accreditation status. The results that have been achieved through this research are as follows:

\section{Data Program and Accreditation}

The number of courses available in the State University of Medan were 72 courses that consist of Diploma III: 2 courses, Bachelor Degree (S1): 49 courses, Master Program (S2): 16 courses, and the Doctoral Program (S3) : 5 study Program. Distribution of the number of courses in the State University of Medan as in Figure 2. 


\section{Figure 2, Distribution of Study Program at State University of Medan}

Distribution of Study Program Amounts

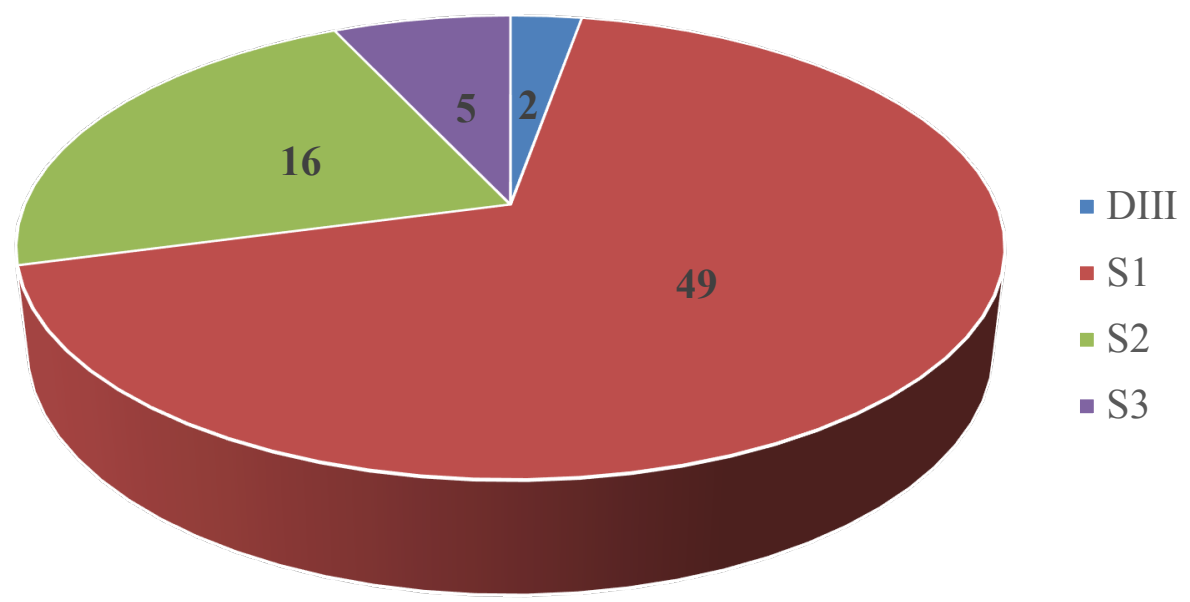

\section{Readiness Questionnaire instrument Facing Study Program Accreditation Criteria 9.}

The questionnaire has been prepared consisting of 11 grains of questions that will reveal some of the data the study program include: a) accreditation and scores, b) the period of validity of the accreditation, c) preparation courses for accreditation next, d) assisting the preparation of a form that is obtained from universities, e) availability of required documents, f) the fulfillment of the needs of the document, g) responses related to changes in the accreditation system, h) understanding of the accreditation system is new, i) the strategy preparing for the accreditation to the new system, $\mathrm{j}$ ) the constraints faced by the study program and $\mathrm{k}$ ) input to the readiness of the study program accreditation facing 4.0 (9 criteria). The instrument has been prepared by the editorial team of the instrument then validated by the expert as much as 3 people.

\section{Manual Preparation Instrument Program Accreditation.}

The guidebook has been prepared sourced from BAN-PT that can be used by the study program in preparing the documents required by accreditation 4.0 with 9 ratings criteria. In the guidebook criteria outlined a new accreditation minimal accreditation based on national standards of higher education (NS-Higher Education). The guidelines also explain the rules of assessment, assessment criteria, accreditation of the new instrument and guide formulation. With this guide is expected to facilitate the study program to prepare and face the next accreditation process.

\section{Data Results Through Readiness Questionnaire Instrument Program.}

Based on the search result data is done by using a questionnaire that has been given to each of the courses that are environment Medan State University gained as much as 36 data. The study program which is still in the accreditation of B amounted to 8 courses with an average value of 342 and the accreditation with an average value of 369 . These data provide an initial overview information that the course that has a value of accreditation B still requires a fairly high value addition if you want to get the value of accreditation A. While the courses that have earned accreditation with an average value of 369 is also not too secure to be able to maintain accreditation has been obtained. Therefore both courses that have already received grades $\mathrm{A}$ and the value B still needs the attention of all parties to improve their respective accreditation courses that have an impact on university accreditation. Prodi akreditas percentage expiration time can be seen in Figure 3 below. 


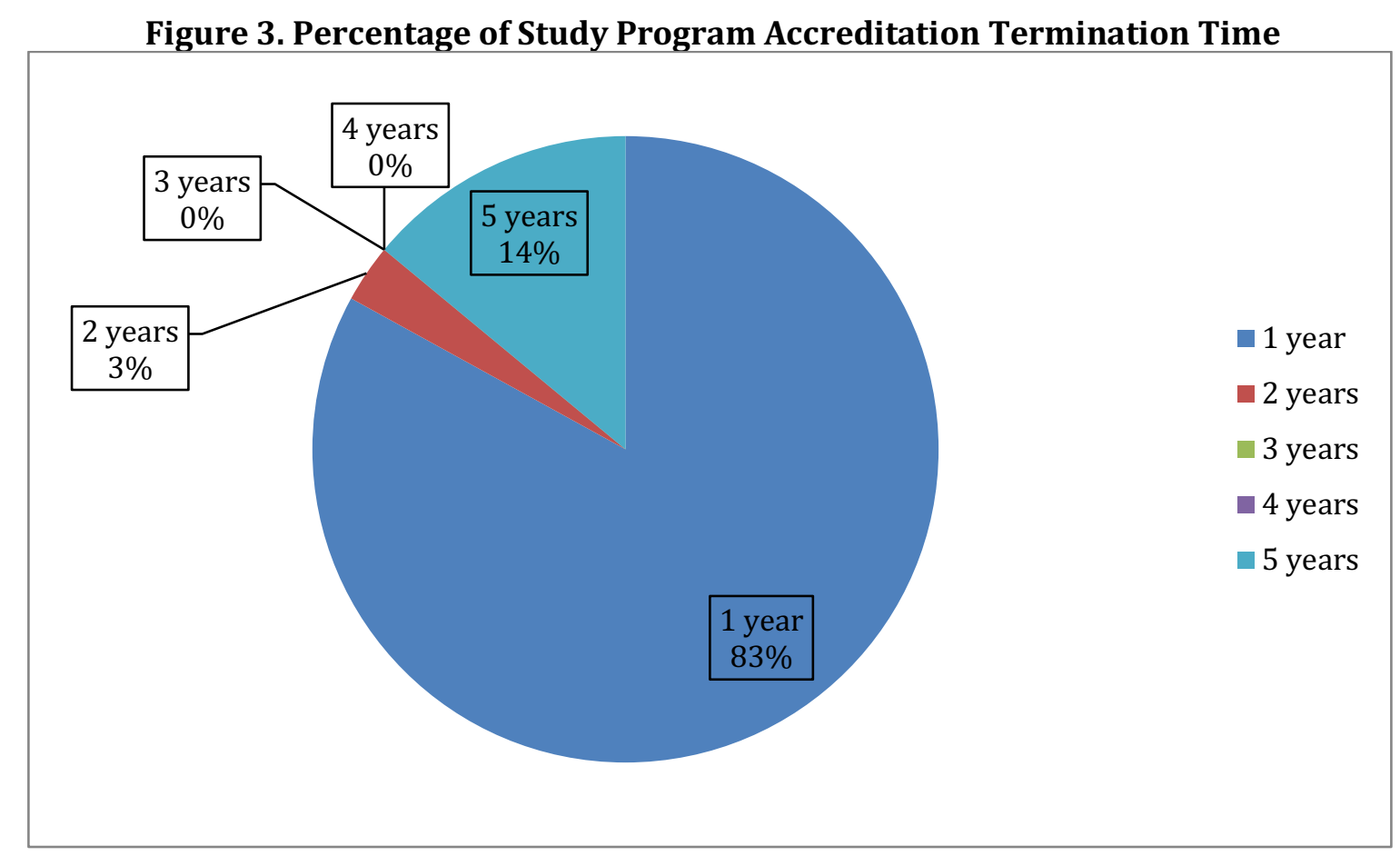

Based on the distribution of the data in Figure 3 above illustrates the need for better preparation caused by the expiry of accreditation majority live one year longer. Therefore it is necessary to do a variety of systematic steps and work together in preparing the documents of accreditation in order to obtain the maximum value.

Picture data that has been obtained from questionnaire data tabulation showed some variation period of validity of the accreditation, accreditation period barakhir where the majority of the same year with the accreditation of the University in 2021. Figure 4.3 shows data on the expiration of accreditation in the environment University of Medan

If we explore the readiness of each program of study that will expire accreditation for another year, obtained the information that there are courses that have not been preparing for reaccreditation. While the accreditation system will come already using the new system that requires a wide range of understanding and adjustment. The picture percentage readiness to face reaccreditation study program is shown in Figure 4. 


\section{Figure 4. Percentage of study program readiness to face re-accreditation}

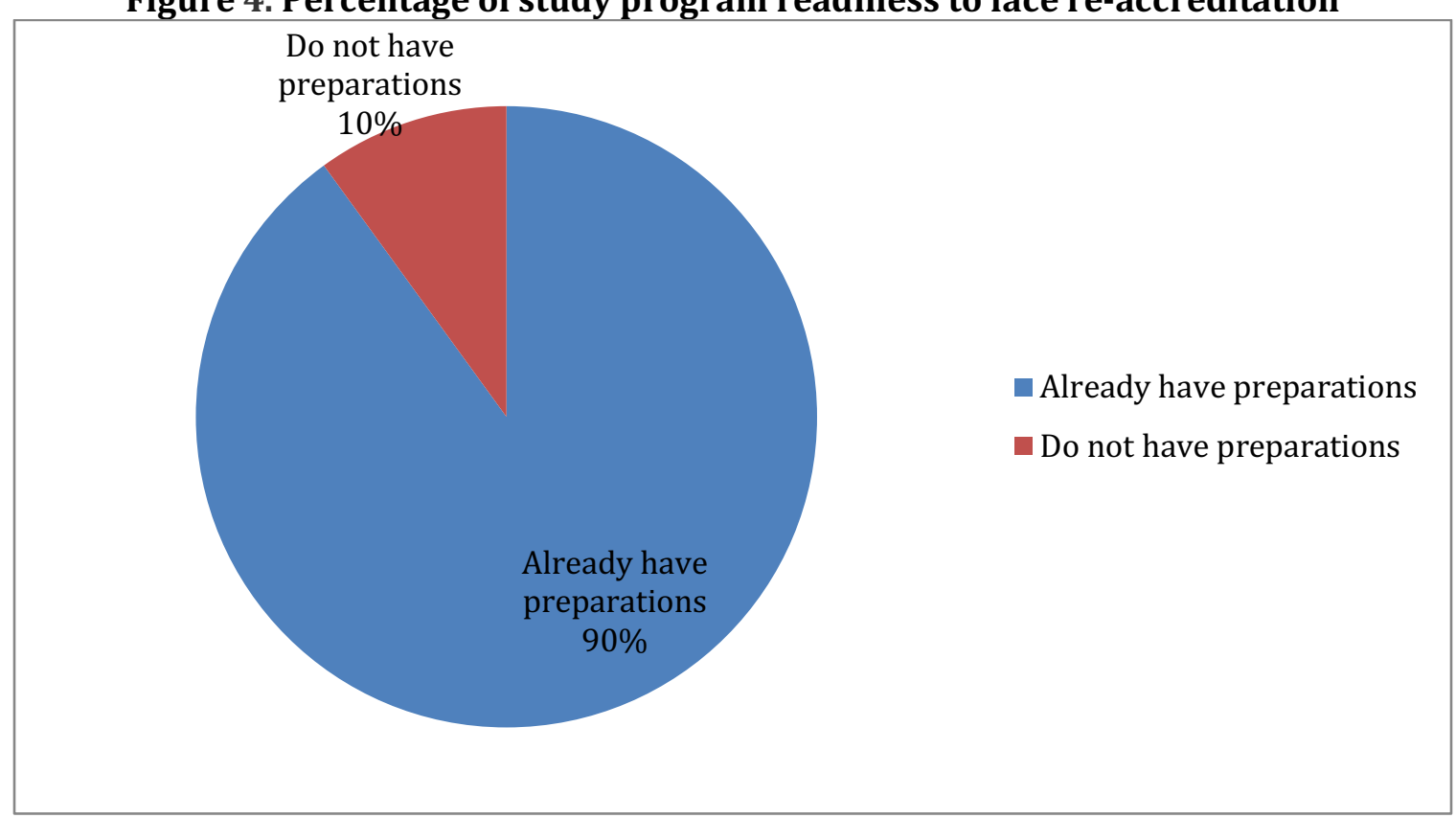

Readiness is referred to in the above data is that each course has a wide variety of levels of readiness from the mere formation of the drafting team borang to preparedness for each standard. However, in this study can not be expressed this readiness level in a quantitative form. Therefore it is necessary for a continuous accompaniment in order to obtain data that is more real extent of readiness. While $10 \%$ of courses that will enter the reaccreditation one more year, but does not have any preparation. It is also very necessary immediately followed by the various parties to immediately be able to prepare for reaccreditation with the new system.

The study also tried to reveal that approximately $17 \%$ of the study program (Figure 5) states had not received assistance from the party leadership in order to face reaccreditation thereon. Therefore, a range of courses is very much face obstacles in preparation for reaccreditation both in terms of understanding the new system and data acquisition.

Figure 5. Percentage of study programs that have and have not received assistance

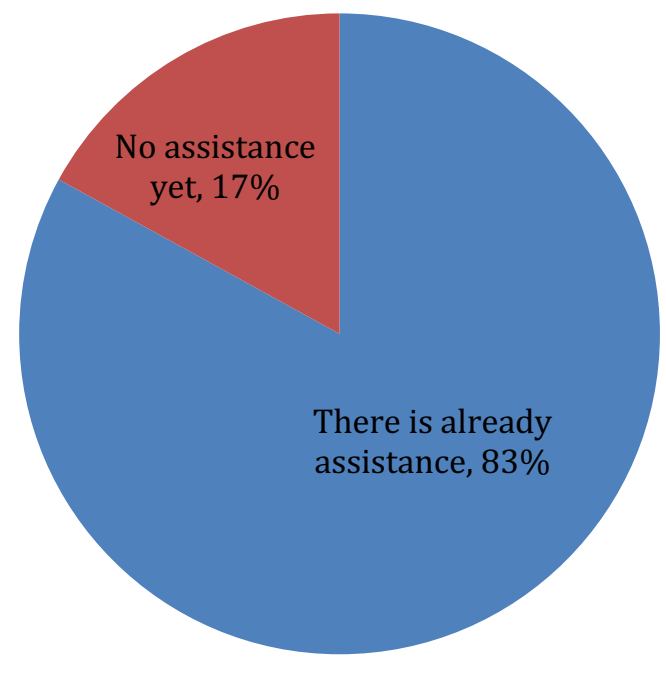

There is already assistance

No assistance yet 
Although various attempts have been made in the preparation of the study program reaccreditation, but the undertakings which do not yet systematic and measured properly. To illustrate the efforts undertaken are:

1. Cooperating with the alumni

2. Collecting data

3. Conducting FGD and learn a new instrument

4. Forming a working team

5. To coordinate with various parties leaders.

The above efforts still face many obstacles, especially in understanding the new system or collection of necessary data. Therefore, most of the courses have a sense of fear to face reaccreditation with the new systems, so it is required continual assistance system.

The level of understanding of each course on the new accreditation system can be seen in Figure 4.6

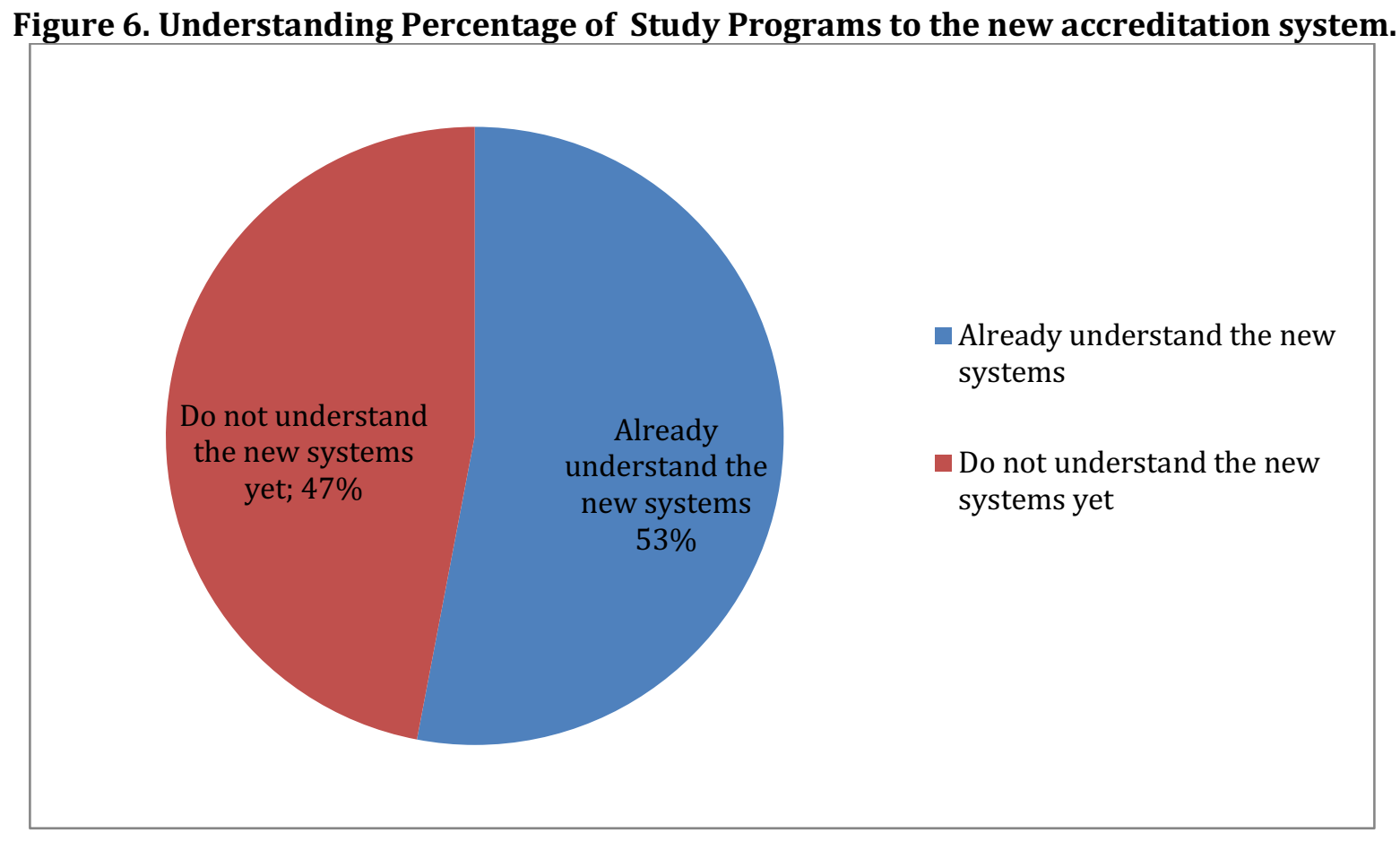

If we observe the picture of the level of understanding of each course to the new system, there will be concerns we would preparedness has been described above is in conformity with the existing guidelines. Therefore we need to make efforts so that courses that will face the reaccreditation have better preparedness and can prepare better and more scalable. Adapaun various attempts to do is to disseminate the new standard system so as to have the same level of understanding. After sosialisi well then the next step is to conduct an ongoing mentoring system so that the level of preparation can be measured properly.

\section{Conclusion}

\section{CONCLUSIONS AND SUGGESTIONS}

Based on research that has been conducted can be summarized as follows:

1. Reaccreditation Studies Program at the State University of Medan is very dependent on the success of mentoring course which is now organized both in preparing for accreditation instruments as well as documentary evidence. Based on existing data 
currently ranked targets of accreditation that will expire next year accreditation was ranked excellent.

2. Factors inhibiting accelerated increase in Study Program accreditation State University of Medan, among others: (a) The absence of a system that can be used to ease the study program to access the data; (B) The level of understanding of each course with the new accreditation system is still low; (C) The lack of assistance in preparing the study program accreditation instruments, while the supporting factors accelerating the increase in Study Program accreditation State University of Medan, among others: (a) Participation of the entire community of course is very good; (B) the infrastructure owned by their respective study program has been appropriate

3. Strategies accelerated increase in Study Program accreditation State University of Medan, among others: (a). Perception related to the new accreditation system in stages; (B) Assistance study program in a sustainable and measurable; (C) Preparation of system data relating to the needs of accreditation instruments that can be accessed by programs with ease.

\section{RECOMMENDATIONS (RECOMMENDATIONS DRAFT POLICY)}

Based on the research results, suggestions for accelerating the upgrading of the accreditation process include:

1. Data systems

Form a working unit which can collect a variety of data required for the fulfillment of accreditation instruments into a single system that can be accessed online by their respective existing courses at the State University of Medan

2. Accompaniment

Empowerment and Development Institute Education Quality Assurance (LPPMP) to socialize in stages and provide guidance to the entire course in a sustainable and scalable.

\section{References}

Austrian Federal Ministry for Transport, Innovation and Technology (BMVIT) Model procedures for co-operation and coordination. Accessed from http://www.transportera.net/about-ent/description-of-ent/procedures-forcooperation.html on May 15, 2019

BAN-PT. 2008.Book I - Manuscript Academic Degree Accreditation Program. Jakarta: BAN-PT. .2008.Book II - Standards and Accreditation Procedures Undergraduate Studies Program. Jakarta: BAN-PT. 2008.-BorangProgram IIIA Book Study. Jakarta: BAN-PT.

2008.Books IIIB - BorangFakultas / High School.Jakarta: BAN-PT.

2008.Book VII - Guidelines for Assessment Assessment Instrument Graduate Program Accreditation. Jakarta: $B A N-P T$.

2008.Self-Evaluation Handbook for Undergraduate Studies Program and Higher Education Institutions. Jakarta: $B A N-P T$.

BAN-PT. 2018. Regulation of the National Accreditation Board for Higher Education Number 59 Year 2018 About the Self Evaluation Report Preparation Guide, Performance Higher Education, and the Matrix Assessment In Higher Education Accreditation Instruments. Jakarta: BAN-PT

Directorate General of Higher Education. 2004.Higher Education Long Term Strategy 2003-2010: Delivering quality colleges. Jakarta: Directorate General of Higher Education.

Republic of Indonesia. 2003.Law Number 20 Year 2003 on National Education System. Bandung: Focus Media. 2005.Government Regulation No. 19 Year 2005 on National Education Standards. Bandung: Nuance Aulia. 2005.Law Number 14 Year 2005 on Teachers and Lecturers. Jakarta: Ministry of Education. 2008.Government Regulation No. 74 Year 2008 regarding Teachers. Jakarta: Ministry of Education. 